\title{
THE APPLICATION OF TASK-BASED LEARNING TO IMPROVE THE QUALITY OF THE TEACHING AND LEARNING PROCESS OF READING IN INDONESIAN SECONDARY SCHOOLS CONTEXT
}

\author{
by \\ Maria Wulandari, S.Pd., M.Hum. \\ IAIN Surakarta [mariawlndr@gmail.com] \\ Syafrianto SM., SS., M.Hum. \\ STMIK EL RAHMA Yogyakarta [sir.ryan@yahoo.co.id]
}

\begin{abstract}
This paper aims to discover the feasibility and the applicability of task-based learning in improving the quality of the teaching and learning process (TLP) of reading in Indonesian secondary schools in relation to the teaching of genre or text types as required by the national curriculum.

This is an action research study which is qualitative in nature. The data were obtained through observations and interviews with the students and the collaborators. They were in the forms of field notes, interview transcripts, and photographs. In addition, this research applied the investigator triangulation, the theoretical triangulation and the time triangulation.

The actions implemented in this research are discussing new vocabulary items and guessing meaning from context, applying skimming and scanning strategies, discussing grammar related to the text, conducting a question/answer game, providing various materials from different sources, and applying group/pair work. The results of the research show that the students' motivation increased. They were more enthusiastic in learning reading. Moreover, the students were interested in various materials presented by the teacher. They could get involved actively in the reading learning process. In addition, the classroom interaction also increased. The students could interact very well with other students and the teacher. In conclusion, the use of task-based approach with its accompanying actions is effective to improve the teaching and learning process of reading.
\end{abstract}

Keywords: reading, secondary schools, task-based learning, quality teaching and learning process

\section{A. INTRODUCTION}

In most of Indonesian secondary schools, it is widely recognized that reading skill (among the four English language skills) gets a great emphasis. It plays important role in understanding literature or text books and for gaining various information. If the students can master reading skill well, they can easily update their knowledge in order to achieve bright academic future and other achievements. To help students achieve good competence in reading, it is necessary for teachers to establish quality teaching and learning process (TLP) of reading. In doing so, teachers need to pay attention to factors which are possible to affect the reading learning process, that is, linguistic and non-linguistic factor. From linguistic factor, there are at least two components that need to be considered in reading such as the ability of word recognition and comprehension, while from non-linguistic factor, there are also some components that are crucial to support the reading learning process such as the motivation to learn, the interaction during the learning process, and the material used as the sources of reading. In fact, not all teachers are aware of those factors. Hence, there are still many problems found in the reading class, for example, the problem of students' motivation in reading. Students are often less motivated to actively engage in the activities in the reading class. Besides, the problem of interaction often appears in some practices of reading teaching and learning process. It is caused by the teacher's dominance during the reading teaching and learning process. The other common problem of reading is related to the students' reading ability. There are also activities/tasks implemented in the teaching and 
learning process of reading which are not optimal to improve the students' reading ability. Moreover, the material that teachers give to students in the reading class was monotonous.

To solve those problems, some researches had been conducted by the researchers which resulted in various approaches, methods, techniques and strategies that can be used to improve the quality of the teaching and learning process of reading. One of the approaches which is proposed by the researchers lately is Task-Based Learning (TBL) - it is an offshot of Communicative Language Teaching (Kumaradivelu, 2006). This is a relatively new approach for English teachers especially in Indonesia secondary schools. Since this is new-although many researchs has shown its effectiveness, teachers still have various assumptions towards this approach. Many of them assume that it is impossible for TBL to improve the quality of TLP of reading. They think that tasks will not make any difference to the quality of TLP of reading - as they always give tasks but they still fail to make the students' reading skill improved. Moreover, tasks will only burden the students, decrease their motivation and make a barrier in learning if the students give up with the tasks. Those relatively negative assumptions shouldn't be addressed if teachers and educators understand the essence of task-based learning and its applicability to the reading classroom. Therefore, this paper attempts to provide understanding that TBL can be feasible and is an effective teaching approach to improve the quality of the teaching and learning process of reading.

\section{B. THEORETICAL REVIEW \\ The Teaching of Reading}

Based on the recent curriculum of English language teaching in secondary schools in Indonesia, language is seen as communicative resource. The students are expected to learn language not as separate building blocks - learning language features like learning grammar, vocabulary, pronunciation separately - but to learn it through texts. Therefore, the syllabus used is known as textbased syllabus. As the name suggests, the students learn through texts. According to Feez and Joyce (2002: 4), a text is any stretch of language which is held together cohesively through meaning. 'Text' is also bounded to context and it can be divided into written text and spoken text.

Reading is one of the activity or skill which is closely related to written text. As stated earlier, every text brings meaning, therefore the ultimate goal of reading is actually comprehension to the meaning itself (Lipka and Siegel, 2011: 1873). In relation to comprehension or understanding a text, Torgesen (cited in James and Reign, 2001: 23) stated that there are some factors which need to be considered such as motivation, interest, vocabulary, general knowledge, knowledge of particular subject, word identification skills, reasoning ability, use of effective strategies to identify main ideas and supporting detail, and an appreciation of the text structure. Therefore, in the reading learning process, the teachers need to be aware of those factors in order that the students can understand very well. The teacher should know the students' learning needs and their difficulties in reading. The teachers can encourage them in learning reading through some ways such as by assisting them in learning vocabularies and learning how to use the strategies of reading. Strategies are useful to be taught because it can help the students to improve the reading comprehension as well as the efficiency of reading like what have been stated by Janzen in Richards and Renandya (2002: 289). In addition, the teacher should also make the students interested in learning so that they can be motivated. To make the students motivated, the teachers can establish a pleasant and relaxed atmosphere in the classroom (Brown, 2001: 81). If the students enjoy the learning process, they will engage more so that the teaching and learning process will be successful. If the process is successful, it can lead to the improvement of students' reading ability.

\section{Task-Based Learning}

Richards and Rodgers (2001: 223) states that Task-Based Learning refers to an approach based on the use of tasks as the core unit of planning and instruction in language teaching. Another definition is provided by Richards and Schmidt (2002: 540), Task-Based Learning is a teaching approach based on the use of communicative and interactive tasks as the central units for the planning and delivery of instruction.

Related to the teaching and learning process of reading, there are various tasks that can be created by teachers. The use of tasks actually can support effective reading class. Richards and Schmidt (2002: 540) states that in language learning, 'task' can be an effective foundation because 'task' can facilitate 
the students to interact and communicate which then can promote negotiation of meaning and also develop the students' awareness of grammar. The interaction that the students can do through communicative tasks are, for example, seeking clarification about the task, or trying to discuss and comprehend the tasks which are given, asking the teacher about something which is related to the tasks, giving opinion and information exchange to fulfil the tasks together, and other kinds of interaction.

\section{The Advantages of Task-Based Learning}

According to Richard and Rodgers (2001:223), the use of tasks can provide better contexts because it can engage the learners more in the learning process so that the learners have better opportunities to learn. Richard and Rodgers (2001: 228) also state that "task provide better opportunities for both input and output requirements, which are believed to be key processes in language learning." They add that tasks can be used to support the process of negotiation, modification, rephrasing and experimentation which are beneficial for the success of second language learning. SLA researches have shown some considerations for applying task-based language teaching since it can give input-output practice, negotiation of meaning and transactionally focused conversation (Richard and Rodgers, 2001: 229). Taking the advantages of task-based language teaching, Skehan (cited in Richard and Rodgers, 2001: 229) also suggests that "tasks can be designed along a cline of difficulty so that learners can work on tasks that enable them to develop both fluency and an awareness of language form."

From the advantages above, it can be concluded that there are many advantages of task-based learning. First, it can engage the students in the teaching and learning process. Second, it gives the students better opportunities to learn because it includes negotiation of meaning. Third, it also gives a lot of chance for the students to learn by doing because the students are required to engage in physical activity during the accomplishment of tasks. Finally, task-based learning can help the students to develop their awareness about focus on form. In other words, Task-Based Learning can create an enjoyable learning condition. By creating enjoyable learning condition it is expected that the teaching and learning process of reading can run effectively and efficiently.

\section{RESEARCH METHOD \\ Research Design}

This study is qualitative in nature. It described how the actions will be implemented and how the effects on the teaching and learning process of reading. The qualitative data were taken through observations, interviews and photograph taking. The design of the study is action research. Elizabeth (in Burns, 2010: 5) stated that action research is a research carried out in the classroom by the teacher of the course mainly with the purpose of solving a problem or improving the teaching and learning process. Moreover, Carr and Kemmis in Hinkel (2005: 241) stated that action research is a form of investigation done by participants as a reflection of their own practice which aimed at improving the practices and understanding the practices and situations in which the practices are done.

\section{Setting and Participant}

As stated previously, the aim of this study is to find out whether or not Task-Based Learning is able to improve the quality of the TLP of reading in Indonesian secondary schools. Dealing with this, the researchers conducted an action research in one of secondary schools in Indonesia. It is at SMPN 1 Pajangan, Bantul, Yogyakarta Special Region.

The participants in this research were the students of class VIII D of SMPN 1 Pajangan, Bantul, Yogyakarta Special Region. The class consisted of 36 students. There were 19 girls and 17 boys. They were chosen as the subjects of the research by considering the result of the discussion with the English teacher. There were some considerations of choosing the students of class VIII D of SMPN 1 Pajangan. First, it was related to the students' reading ability. The students of class VIII D had the lowest average of reading score if it is compared with the reading score of other classes in the same grade. Second, that problem was also culminated by the problem of students' motivation and interaction during the learning process which is not optimal. Therefore, based on the complexity of the problems, the researchers and the collaborator decided to choose class VIII D of SMPN 1 Pajangan as the subjects of this research. 


\section{Research Procedure \\ Planning}

In this step, the researchers made plan of actions to be implemented to improve the reading teachinglearning process. The researchers prepared the lesson plan based on the curriculum and syllabus from the school. Meanwhile, the materials and other instruments needed in the research were selected. The researchers tried to find the materials which are suitable based on the indicators of learning that would be achieved during the teaching and learning process if reading.

\section{Action}

After planning the actions, the researchers and the English teacher implemented the actions in the teaching-learning process of reading. The actions were conducted until the improvement has been achieved. During the actions, the researchers and collaborators observed the process.

\section{Observation}

During the process of implementing action, the researchers and the collaborators observed the events happened in the classroom. The observation was done to find out the success of the action and the problems that occurred during the implementation. The researchers, then, wrote notes about everything that happened in the class during the action.

\section{Reflection}

Based on the observation done in the previous step, the research members did reflection about the actions. Reflection was carried out by discussing the success of each action and the problems that occurred during the actions. In this step, the researchers and the collaborators evaluated the problems and tried to find the solution so that the researchers could do better in the next cycle.

In summary, the actions implemented in this action research study were based on planning, acting, observing, and reflecting. The researchers and the collaborators worked together in finding the obstacles and weaknesses of students' reading ability, identifying the problems, making a plan again, carrying out the actions, and doing the observation and reflections of the actions

\section{Data Collection \\ Observation}

McKechnie (2008: 578) states that observation is one of the most fundamental research approaches that involves collecting impressions of the world using all of one's senses, especially looking and listening, in a systematic and purposeful way to learn about a phenomenon of interest.

The observation conducted to know what happens in the classroom when the action is implemented. The researchers and the collaborators observed the teaching and learning process of reading to obtain the information about the success of the actions and the problems that occurred during the implementation of the action. To support the observation, the researchers provided observation sheet which included some steps in implementing the actions. It was done in order that the observers could observe whether the actions done as planned before or not. Beside observation sheet, another instrument was field note. Field note was used to write notes about everything that happened in the class during the actions.

\section{Interviews}

According to Brinkmann (2008: 470), an interview is a conversation where information is observed and knowledge is created through the interaction between an interviewer and interviewees. In this research, the researchers developed some questions as interview guideline but she will allow for some flexibility according to how the students and the teacher respond. It means that the interview questions were planned but if there were some unexpected responses from the students and the teacher, the researchers allowed it to get more detail data.

\section{Photograph Taking}

The researchers took some pictures of the classroom activities during the implementation of the action research cycle to support other data in this research. Photographs hopefully could give clearer figures or fact of how the research is done.

\section{Data Analysis}


In this action research study the qualitative data analysis were used. The qualitative data analyses were done by collecting the data from the interview transcripts, field notes and photos. After collecting those data, the researchers identified the data and classified them. At the end of the analysis, the researchers drew conclusion. These steps were adopted from Miles and Huberman's explanation in Punch (2005: 197). They say that the qualitative data analysis consists of three flows of activities that are data reduction, data display, also drawing and verifying conclusion.

\section{Validity and Reliability}

This research is conducted by following five types of validity by Burns (1999: 161-162). They are democratic validity, outcome validity, process validity, catalytic validity and dialogic validity. Democratic validity means that in the process of action research, the researchers collaborated with all parties which become the members of the research such as the teacher, students, headmaster and collaborator to discuss about the process of implementation of task-based approach. Outcome validity means that the research was conducted based on the need of successful learning using task-based approach. Process validity means that the worth of the research took on the process not merely on the results of the research. So, the process was done systematically in order to get the complete information to describe the process in implementing task-based approach. Catalytic validity means that this research was done by considering the principle that this research will be useful and give deep understanding for the researchers and all members of the research and motivating them to do related research. Dialogic validity means that in conducting the action research when the researchers wants to take a decision, the researchers consulted others or other members of the research, the expert or even to the researchers in order to consider the action or to get a conclusion.

To obtain the trustworthiness, the researchers used a triangulation technique (Burns, 1999: 163-164). Burns (1999: 164) proposed four types of triangulation. They are time triangulation, space triangulation, investigator triangulation and theoretical triangulation. Nevertheless, the researchers only used three forms of triangulations, i.e. time triangulation, investigator triangulation and theoretical triangulation.

First, the researchers used time triangulation. Time triangulation meant that the data were collected over period of time. It was done to get a sense of what factors were involved in change processes. The data which were collected through the period of time were compared to formulate questions and the action used to improve the teaching-learning process of reading. Then, the changes related to the improvement in the teaching and learning process of reading were monitored in every cycle.

Besides time triangulation, the researchers also used investigator triangulation. In this form of triangulation, the researchers used more than one observer to collect the data about teaching-learning process of reading. It was done to avoid the bias in the observation. There were at least four observers in this study, i.e. the English teacher of class VIII and the English teacher of class IX as the collaborators and the researchers. In this case, the researchers and the collaborators collected the same data about teaching and learning process related to the researchers's way in presenting the materials, the students' attitude in the class and the class atmosphere. After collecting the data, they crosschecked the data to see the fitness of the data.

In addition to time triangulation and investigator triangulation, theoretical triangulation was also used in this study. Theoretical triangulation meant that the data were analysed from more than one perspective from some theoretical reviews. In this study, the researchers reviewed the theories from some experts of some books.

\section{DISCUSSION}

Reading in secondary schools counts for a big proportion in English learning. It is regarded as the skill which plays important role in learning and grasping knowledge of other language skills such as listening, speaking and writing. Many researches had been done to enhance students' reading skills. However, it is not enough to improve merely in the aspect of reading skills. Most importantly, teachers are necessary to improve the quality of the teaching and learning process of reading because it is inevitable that the 'process' (reading learning process) will determine the 'product' (students' ability in reading).

Studies has shown that Task-Based Learning can maximize the quality of the teaching and learning process of reading. First, it helps students with reading difficulties. It provides opportunities for the students to learn reading skills from different learning task with which they can improve reading 
skills. Besides that, it also provides scaffolding for the students through following the sequence of task-based framework. Second, it offers favorable learning condition through tasks and activities which are motivating. And third, it provides opportunities for the students to engage more in the learning process, resulting in the activities of meaning negotiation so it helps them to get better understanding of the materials. These advantageous aspects of using TBL in teaching reading will be explored later.

\section{The Framework of Task-Based Learning (TBL)}

A number of literature proposes the framework for Task-Based Learning (for example Nunan, 1985; Prabhu, 1987a; Skehan, 1996; Willis, 1996). However, this paper will follow the recent literature. Therefore, it will use the stages stated by Edward and Willis (2005: 26). In terms of the content or activities of the stages, this is actually almost the same with the previous literature mentioned above. The difference is only on the terms used for the stages of the implementation of Task-Based Learning. Some of the previous literature used the terms: pre-task, task, and post-task while the newest terms used by Edward and Willis stated that the three stages are: pre-task, task-cycle, and language focus. Pre-task stage aims to give the students preparation before they are provided with the core materials of reading. This stage provides students with comprehensible input. In this stage teachers introduce the topic or the materials through some activities like warming-up, brainstorming, or eliciting. Besides that, a language support is also given to strengthen the students' ability to receive the next materials. The language support activity that can be done is various, for example, teachers can build their vocabulary knowledge or give them comprehension questions about the reading materials. Sometimes, in this stage, teachers can begin giving the students a practice to do the tasks for the next stage. The students are given the time to understand the goal and the outcome of the task. Therefore, it can be summarized that pre-task stage has, at least, three functions, that is giving comprehensible input to the students, providing language supports and facilitating students to prepare the next tasks in the next stage.

In task-cycle, the students do the main learning activity through tasks. There are three sub-phases including task, planning, and report. In task phase, the students do the reading task in pairs or group in a certain time. The groups can be determined by the teachers or the students. This is based on the condition in the classroom. The group can be set differently from one topic of lesson to another so that the students will not get bored. Besides that, the tasks that the teachers give in this stage may vary based on the indicator of reading skills that the students will achieve. The type of tasks that can be employed will be discussed later in this paper. After the task phase, the students can go through the planning phase. In this phase, teachers give time for students to prepare for the report phase. Teachers help the students with their difficulties in doing the tasks. The students are allowed to ask questions or to clarify something to the teachers about their works before they present it in front of their friends. The teachers can give guidance or check the students' works more closely in this phase. After the time for planning phase is up and the students are ready to present their works, the teachers can give them opportunity to present the works. After the presentation, the teachers should give feedback to the students especially the feedback in the forms of content. The feedback in the forms of form can be delayed for the next activities that will be discussed in the language focus stage below. The activity of giving feedback to the students can be done through discussion so that there will be two-way communication.

The last phase is language focus. This stage aims to enhance the students' awareness on the form of the language they learn. It consists of two sub-phases: analysis and practice. In analysis phase, the teachers conduct a review on the languages items which are closely related to the reading texts and tasks that they have learned in the previous stages. After the students understand the language items and its function, the teachers, then, give opportunity for the students to practice those language items in the practice phase. This practice phase is given to make the students confident with their knowledge. Furthermore, this language items practice is useful to prepare the students in the productive skills, that is writing skills.

\section{Task-Types for Reading Skills by Using Task-Based Learning}

According to Willis cited in Johnson (2008: 186) in task-based learning there are six types of tasks that can be used. They are: listing, sorting and ordering, comparing problem solving, sharing personal experience and creative tasks. In addition to the types of tasks in task-based learning proposed by 
Willis above, there is an early strategies-based typology for developing reading skills which is proposed by Grellet cited in Nunan (2004: 61). Classroom tasks exploiting the strategies by Grellet include ordering a sequence of picture, comparing texts and picture, matching and using illustrations, completing a document, mapping it out, jigsaw reading, reorganizing the information, comparing several texts, completing a document, summarizing and note taking. Richards and Rodgers (2001: 222) also proposes some considerations for selecting and ordering tasks as follows:

1) Procedures, or what the learners have to do to derive output from input

2) Input text

3) Output required

(a) Language items: vocabulary, structures, discourse structures, process ability and so on.

(b) Skills, both macro-skills and sub skills

(c) World knowledge or 'topic content'

(d) Text handling or conversation strategies

4) Amount and type of help given

5) Role of teachers and learners

6) Time allowed

7) Motivation

8) Confidence

9) Learning styles

Therefore, tasks should be chosen based on the need of the reading learning process. When selecting the input for the tasks, the teacher should consider the level of difficulty of language that contains in it. Besides, the teacher need to consider the content of the task which include the language items that will be taught, the micro skills that will be developed, and the topic which is established. Task selection also closely related with the role of the teacher and the students. So, in selecting the task, the teacher should determine both the teacher role and the students' role. The teacher should also consider about the time that will be allocated in order that the teaching and learning process run efficiently. Furthermore, the teacher needs also to consider the students' motivation, confidence and learning styles. By knowing the students motivation as well as students' confidence and learning styles, the teacher can put which task will be presented first and so on.

Related to the task selection, usually some schools have certain textbook in which the tasks are available. However, the teacher should not always rely on those kinds of task because not every task in the textbook can be used to optimally give the students opportunities to learn the skills based on their level of proficiency and interest. It does not mean also that the tasks provided by a certain textbook is not appropriate for the learning of reading, but it means that the teacher need to adjust the tasks to be a meaningful tasks for the students considering the factors or other components supporting reading learning process such as the students level of proficiency, the topic of the reading material, the difficulty of the language in the tasks, and the procedure of doing the tasks.

\section{Some Activities Supporting the TLP of Reading based on Task-Based Framework}

There are many types of tasks that can be used in TBL framework as mentioned in the previous section. Regarding to the improvement of the process as well as product of the teaching and learning of reading, there are some possible activities that I can suggest related to the use of Task-Based Learning. These activities of reading are considered appropriate especially in the context of Indonesian secondary schools because the English teaching curriculum in Indonesia demands the teachers and the students to conduct reading learning process which mostly deal with the texts or certain genre such as narrative, recount, descriptive, procedure, etc.

\section{Pre-Task Stage}

As mentioned in the explanation, in this stage the teachers can provide students with the activity of preparing themselves to approach the core reading material. Three essential activities of reading that can be proposed in this stage is guessing meaning from context, giving the model of applying skimming and scanning strategies and conducting a question/answer games. For the first activity, it is beneficial for the students. The action of guessing meaning from context helped the students when they deal with difficult words. It also helps the students in comprehending the texts. Meanwhile, the 
action of discussing new vocabulary items can make the students get closer with the topic and enrich their vocabulary knowledge. By having much knowledge of vocabulary, the students were helped in understanding the meaning of the texts more easily. The more vocabulary items they master, the better their understanding of the texts. Meanwhile, giving the model of applying skimming and scanning strategies can also be considered useful in this stage. The teachers can give the model of how to skim and how to scan the texts to find out the general and the detail information of the texts. This activity aims to help the students in understanding the reading texts given by the teachers. Conducting a question/answer game can also be an alternative of activities in the pre-task stage. This activity aims to motivate the students as well as make them understand with the reading materials. The use of game with question and answer activity can engage the students more in the learning process of reading. This is because the question/answer game is exciting and attractive. Besides that, using game can be challenging for them. In addition, the use of comprehension question which are integrated in question/answer game is also believed to be effective for the students to understand the content of the texts and attract the students' attention to deal with the reading materials.

\section{Task-Cycle Stage}

In task-cycle stage the teachers can provide the students with various materials from different sources. Various materials prepared by the teacher will make the materials not monotonous in terms of the sources (texts) and the forms of tasks given by the teacher. The variation of the materials can be effective to give positive influence to the students' interest in reading. Through various materials they are facilitated in rehearsing their reading skills through the tasks which were presented by the teacher. However, the texts needs to be appropriate for the students in terms of its length and its level of difficulty so that the students do not feel frustrated in reading. In this stage the teachers can also apply group/pair work. Some researches stated that the application of group/pair work can be effective in building a good classroom interaction during the teaching and learning process of reading. Group/pair work made the classroom interaction more varied. The interaction between the teachers and the students can be facilitated through group/pair work so that the teachers will not dominate the teaching and learning process. Through planning phase in which the teachers can give close guidance to the students, the students will not ashamed in interacting with the teacher such as by asking the questions, answering the questions and participating in the discussion. Meanwhile, this activity will also make the interaction among the students increased. It was facilitated by the implementation of group work/pair work. In group/pair work, the students can cooperate together in accomplishing the tasks given by the teacher. Besides, they became motivated in learning reading because they group work can facilitate them to help each other when they faced difficulties.

\section{Language Focus Stage}

In this stage, discussing grammar related to the texts can be an alternative activity. This activity can allow the students to increase their awareness of grammar which is an important part of learning reading. The language items that can be discussed are various such as part of speech, tenses, grammatical devices, etc. Through understanding language items, the students can get various benefits especially for helping them in understanding the texts. Having the knowledge of form and function of the language items, the students will comprehend the reading materials more easily. Besides that, by understanding the form and function of certain language item, they will be helped in their productive skill, that is writing skill.

\section{How Task-Based Learning Improve the Quality of the TLP of Reading}

In the previous section, it has been discussed that quality TLP of reading is influenced by linguistic and non-lingustic factors. Given the fact that motivation and interaction are two crucial factors in TLP of reading and reading ability is always necessary to be improved, it is important to discuss how TaskBased Learning deals with those aspects.

\section{Motivation}

Task-based learning can create students' motivation in learning reading. Motivation, as mentioned by Torgesen (in James and Reign, 2001: 23) is one of the important factor that influence reading. Therefore, motivation should be enhanced during the teaching and learning process of reading. If teachers want to motivate students they should know the reasons why they are less motivated. Indonesian secondary schools students whose mother tongue is Bahasa Indonesia or other local 
languages commonly find little exposure of English language in their daily activities because English in Indonesia functions as a foreign language. Little exposure of English language can be one of the factors of difficulty faced by the students in learning reading. They consider reading difficult because this activity is not a habitual activity with which they find large opportunity to get exposure. Besides the attitude towards English reading, another common reason of poor motivation usually stated by Indonesian secondary schools students is the difficulty of the texts and tasks which are given by the teachers. Sometimes, teachers give them many tasks which they feel difficult to understand. The problem becomes more complicated, in some cases, because the teachers do not give any model of language or some language supports that can give them guidance to fulfil the task. They also, in some cases, find that they do not understand what actually the goal of the reading learning process. Therefore, it can be concluded that the source of less motivation are: the students' attitude towards reading, the text and task difficulty, the procedure of doing the activities in reading and the statement of goal in the reading activities.

To solve the first problem using task-based learning, teachers can change the students' attitude towards reading from negative to positive by creating condition for teaching and learning process of reading. Reading might be considered as passive and boring activity by the students. Actually this negative attitude can be changed into positive one through task based learning for example by creating reading tasks/activities which are attractive. In this paper, I propose the activities called question/answer game, as discussed previously, which can arise the students' motivation in reading. Through the goal which is set through the task, the students are motivated to read and understand more about the text or the passage. Goal is also important component in a task as stated by Nunan (2004: 41). The teacher can also give various procedure in doing the tasks in order that the students do not easily get bored with the task. Procedure is also a crucial component in developing an effective and efficient task as stated by Nunan (2004: 52). Text difficulty can be solved by giving the students context (topic) and comprehensible input. By giving the topic which are familiar to them, it will help them because they have background knowledge and they can comprehend more easily. Although it should be familiar with the students, the teachers should also give some new vocabulary or words in order to develop their vocabulary. This is in line with Krashen who states that, for learning, the input given should be one level above the current proficiency. The task difficulty can be solved by giving guidance through model. Guiding the students by giving the model first and then ask them to answer the questions together in the pre-task stage. The teachers should also correct the students' wrong answers indirectly so that it can lower the students' anxiety in learning reading. This is in line with Krashen in Gass and Selinker (2008: 402) who state that for comprehensible input to take place, the condition of the classroom needs to be manipulated, meaning that, teachers should consider the affective filter proposed by Krashen such as motivation, attitude, self-confidence and anxiety.

\section{Interaction}

Task-based learning can enhance the quality of interaction in the reading classroom. Interaction is an important part of the successful teaching and learning process. There are three kinds of interaction. They are teacher-student interaction, student-student interaction, and interaction between the student and the materials or reading texts. The stages in task-based learning provides opportunities for the teachers as well as the students to establish the two-way interaction and communication. This interaction can be reflected through the whole stages of task-based learning. For example in pre-task stage, the teacher-students interaction can be maximized through the brainstorming and elicitation activity about the topic of the reading materials. Besides that, the student-student interaction and the student-material interaction can be maximized during the task-cycle stage because the students are exposed with reading materials and they can do the task in group/pair work. Group/pair work gives the students opportunity to exchange information, to share and to help each other to achieve the outcome of the tasks. In group/pair work the teacher-students can also occur especially when the teacher give the guidance to each group or whenever the students ask for help to the teachers. Furthermore, the teacher-students interaction can be realized in the language focus stage in which the students can ask feedback and teachers can have discussion with the students about language items presented in the texts. Task-based learning creates favorable learning condition with a two-way interaction. It is proven to be effective to support the teaching and learning process of reading. This interaction occurs because the teacher and the students can fulfil their roles effectively as stated by 
Richards and Rodgers (2001: 235-236). The students plays role as group participant, monitor and risktaker and innovator while the teachers play role as selector and sequencer of tasks, preparing learners for tasks and consciousness raising. If the students and the teachers can do their roles effectively and efficiently, the quality interaction in the teaching and learning process of reading will improve and automatically will give better learning condition which support students in enhancing their reading ability.

\section{Reading Ability}

Task-based learning is believed to enhance the students' reading ability as the result of the quality teaching and learning process of reading. Reading ability is the product of reading learning process. Reading ability can be defined as the competence that students have for understanding and applying reading macro and micro-skills as stated in Brown (2001: 307). For secondary schools in Indonesia, the skills of reading that the students should achieve is stated in the syllabus. Task-based learning is proven to be effective in enhancing the students' reading ablity because it is possible to cover the two types of skills that is macroskills and microskills. According to Brown (2001: 307) macroskills of reading includes, for example, develop and use a battery of reading strategies such as scanning, skimming, detecting discourse markers, guessing the meaning of words from context, and activating schemata for the interpretation of texts. Meanwhile microskills of reading includes, for example, recognize grammatical word class (nouns, verbs, etc.), systems (e.g. tense, agreement, pluralization), patterns, rulers, and elliptical forms. Task-Based Learning facilitate students and teachers to integrate those two types of skills in one sequence of teaching and learning process of reading (pre-task, taskcycle and language focus). In other words, TBL can be an ideal sequence of reading learning process since it provides not only the comprehension on the content of the reading material but also it raises the students' attention on form (language items). TBL can give students opportunity to learn content through the help of strategies for reading such as skimming and scanning. TBL also concerns about focus on form. This is important because the students of secondary schools in Indonesia should be given explicit instruction of grammar.

TBL also provides students with the application of scaffolding principles so that it can help the students who have difficulties in reading. Scaffolding is manifested through the sequence of taskbased learning. For example in the pre-task the teachers prepare the students with the background knowledge and ensure them with comprehension question as well as the model of task that they will perform later. These example of activities in the pre-task stage can be effective to provide them scaffolding. In task-cycle stage, it is obvious that the teachers give opportunity to do the task through pair/group work in order that the students do not feel that they are burdened at first. However, whenever the students are ready to perform the task individually, they can try to do the task individually. This example is also an illustration of the scaffolding principle which is applied in taskbased learning.

In sum, task based learning help students improve their reading ability. Through various tasks/activities which focus on content as well as form, the students' reading ability will improve since they can practice the macroskills and microskills effectively in the integrated sequence of TaskBased Learning. Besides that, scaffolding provides students with opportunities to learn with the help of teachers and other students before they can perform their skills individually.

\section{E. CONCLUSION}

This paper has briefly showed how Task-Based Learning, an offshot of Communicative Language Teaching approach, is effective and feasible to be applied to improve the quality of the teaching and learning process of reading. As elaborated in this paper, this is based on at least three reasons. First, it deals with reading ability. It helps students with reading difficulties. It provides opportunities for the students to learn reading skills from different learning tasks and scaffolding principle which includes in the learning process. Learning tasks help the students improve reading skills. Scaffolding helps students to go through learning process with guidance before they can be an independent learners. Second, it creates motivation. It offers favorable learning condition through tasks and activities which are motivating. And third, it creates good interaction. It provides opportunities for the students to engage more in the learning process, resulting in the activities of meaning negotiation so it helps them to get better understanding of the materials. 
Considering that Task-Based Learning is useful and effective to establish quality teaching and learning process of reading, it is recommended that this approach be applied especially for teaching secondary school students to help students understand various genres or text types which is required by the curriculum of English language teaching in Indonesia.

\section{REFERENCES}

Brinkmann, S. 2008. “Interviewing”. In Lisa M. Given Ed. The Sage Encyclopedia of Qualitative Research Methods (pp. 470-472). Thousand Oaks, CA: Sage Publications, Inc.

Brown, H.D. 2001. Teaching by Principles: An Interactive Approach to Language Pedagogy. ( $2^{\text {nd }}$ edition). New York: Addison Weslye Longman, Inc.

Burns, A. 1999. Collaborative Action Research for English Language Teachers. Cambridge. Cambridge: Cambridge University Press. 2010. Doing Action Research in English Language Teaching: A Guide for Practitioners. New York: Routledge.

Edwards, C. and Willis, J. (Eds). 2005. Teachers Exploring Tasks in English Language Teaching. New York: Palgrave Macmilan.

Feez, S. and Joyce, H. 2002. Text-based Syllabus Design. Sydney: Macquarie University Press.

Gass and Selinker. 2008. Second Language Acquisition: An Introductory Course. New York: Routledge.

Hinkel, E. 2005. Handbook of Research in Second Language Teaching and Learning. New Jersey: Lawrence Erlbaum Associates, Inc.

James, B. and Reign, W. 2001. Reading and Learning Difficulties: Approaches to Teaching and Assessment. Camberwell: The Australian Council for Educational Research Ltd.

Johnson, K. 2008. An Introduction to Foreign Language Learning and Teaching (2 ${ }^{\text {nd }}$ edition). Edinburgh Gate: Pearson Education Limited.

Kumaravadivelu, B. 2006. TESOL Methods: Changing Tracks, Challenging Trends. TESOL Quarterly 40, 59-81.

Lipka, O. and Siegel, L. S. 2011. The Development of Reading Comprehension

Skills in Children Learning English as a Second Language. Retrieved from http://link.springer.com/article/10.1007\%2Fs11145-011-9309-8\#close

McKechnie, Lynne E.F. 2008. "Observational Research". In Lisa M.Coiven (Ed). The Sage Encyclopedia of Qualitative Research Methods (pp. 470-472). Thousand Oaks, CA: SAGE Publications, Inc.

Nunan, D. 2004. Task-Based Language Teaching. Cambridge: Cambridge University Press.

Nunan, D. 1985. Language Teaching Course Design: Trends and Issues. Adelaide: National Curriculum Resource Centre.

Prabhu, N.S. 1987a. Second Language Pedagogy. Oxford: Oxford University Press.

Punch, Keith F. 2005. Introduction to Social Research: Quantitative and Qualitative Approaches. London: SAGE Publications, Ltd.

Richards, J. C. and Renandya, W. A. 2002. Methodology in Language Teaching: An Anthology of Current Practice. Cambridge: Cambridge University Press.

Richards, J. C. and Rodgers, T. S. 2001. Approaches and Methods in Language Teaching. Cambridge: Cambridge University Press.

Richards, J. C. and Schmidt, R. 2002. Dictionary of Language Teaching and Applied Linguistics. London: Longman.

Skehan, P.1996. A Framework for the Implementation of Task-Based Instruction. Applied Linguistics, 17, 38-62.

Willis, J. 1996. A Framework for Task-Based Learning. Essex: Longman. 
Jurnal Inovasi Pendidikan MH. Thamrin, vol. 2; Maret 2018

54 | P a g e 